\title{
Alcohol's evaporating health benefits
}

\author{
Industry lobbying and promotion are rife and unchecked by governments
}

\author{
Mike Daube professor of health policy \\ Curtin University, GPO Box U1987, WA 6845, Australia
}

Given the harms attributed to alcohol use, it is not surprising that reports ${ }^{12}$ showing possible mortality benefits for low level users attracted enthusiasm among consumers, the media, and the alcohol industry, along with those who welcomed this as a positive response to accusations that calls for action were based on moral fervour. These apparent benefits are now evaporating, helped along by an important contribution in this week's issue (doi:10.1136/bmj.h384). ${ }^{3}$ Through analyses based on the Health Survey for England, particularly designed to identify whether any reductions in mortality risk were greatest in older populations, Knott and colleagues show that if there is any beneficial dose-response relation, it is limited to women aged 65 or more - and even that association is at best modest and likely to be explained by selection bias. ${ }^{3}$

From the early days, headlines such as "a few drinks may help curb heart attacks" ${ }^{4}$ promoted messages around alcohol's cardioprotective properties; many doctors felt comfortable advising patients that alcohol consumption could be beneficial and politicians used evidence on possible benefits to justify their failure to act on reducing harms. ${ }^{5}$

Alcohol companies and their organisations assiduously promoted this evidence, both to reassure their customers and to argue against population level policies aimed at reducing the harms. ${ }^{6}$ After the Australian alcohol industry organisation Drinkwise was established in 2005, one of its first documents devoted as many pages to outlining the health benefits as it did the harms (available from the author on request). Current alcohol industry websites still include advice such as "Thirty years of robust biomedical, clinical, and epidemiological evidence support a significant inverse relationship between moderate drinking and CVD,"7 "the regular, moderate consumption of wine promotes short- and long-term cardio-protective effects and may reduce the risk of coronary artery disease, ischaemic stroke and heart failure associated with coronary artery disease," ${ }^{8}$ and "wine is certainly not a risk factor for cardiovascular disease, which accounts for nearly $40 \%$ of all deaths in Australia." 8 Groups closely associated with the industry have actively promoted advice about alcohol's benefits, including conferences focusing primarily on these, ${ }^{9}$ and commentary such as "simple dietary measures such as light to moderate alcohol and wine consumption to supplement a healthy exercise and nutrition routine, or as an adjunct to prescription medicines when appropriate, may be needed to maintain an ageing population." 9 After the early euphoria, health authorities became much more cautious, not least out of a concern that the benefits were being over-promoted. Heart foundations now emphasise that nobody should be encouraged to drink for the sake of their health. ${ }^{1011}$

The caution was justified. Research over recent years leads inexorably to the conclusion that for a range of reasons, including confounding and selection bias in the papers generally cited, even low level alcohol consumption is unlikely to protect drinkers from cardiovascular disease. ${ }^{12-15}$ A recent mendelian randomisation meta-analysis further concluded that "reductions of alcohol consumption, even for light to moderate drinkers, may be beneficial for cardiovascular health."16

What conclusions should we draw from this emerging evidence, including Knott and colleagues' new study $?^{3}$ Firstly, in health as elsewhere, if something looks too good to be true, it should be treated with great caution. Secondly, health professionals should discourage suggestions that even low level alcohol use protects against cardiovascular disease and brings mortality benefits. Thirdly, health advice should come from health authorities, not from the alcohol industry, and, finally, the alcohol industry and its organisations should remove misleading references to health benefits from their information materials.

Governments around the world are unwilling to take on the formidable economic power of the international alcohol industry. They balk at every obstacle on the course-from taxation to legislated curbs on advertising and sponsorship, evidence based warning messages, and strong, well funded education programmes. Instead they prefer to listen to the siren songs of cooperation. Small wonder that the World Health Organization's director general has expressed concern about "efforts by industry to shape the public health policies and strategies that affect their products," noting that "When industry is involved in policy-making, rest assured that the most effective control measures will be downplayed or left out entirely." ${ }^{17}$

The recently appointed chief executive of the British Civil Service, John Manzoni, remains a director of SAB Miller, ${ }^{18}$ one of the world's largest alcohol companies (and nearly $30 \%$ owned by the Altria-Philip Morris tobacco group, which has three 
nominees on the board ${ }^{19}$ ). The SAB Miller Talkingalcohol.com website advice on "alcohol and health" typifies approaches by the industry, in offering information about possible health benefits ahead of any discussion of harms - which are then portrayed in generalised terms that play down the role of alcohol or the company's own responsibilities. Indeed, the same website promotes further health rationale for use of the product- "Since beer is made from wholesome raw materials, such as cereal grains (e.g., barley, wheat and sorghum), hops, yeast and water, it is a source of natural protein, antioxidants, is plentiful in B vitamins, and minerals (such as silicon, calcium, potassium and magnesium), and is a source of soluble fibre." ${ }^{20}$ What hope is there for determined action when leaders of companies providing this kind of advice are at the very heart of government, and there are several parliamentary all party groups championing the interests of the alcohol industry ? $^{21}$

Reducing the massive health and social harms caused by alcohol will not prevent sensible use and enjoyment of alcohol. Globally, more than three million deaths each year are attributable to alcohol. ${ }^{22}$ The real mortality benefits will come from determined action at the political level, not outdated advice and wishful thinking.

Competing interests: I have read and understood the BMJ policy on declaration of interests and declare the following interests: none.

Provenance and peer review: Commissioned; not externally peer reviewed.

1 Klatsky AL, Friedman GD, Soegelaub MS. Alcohol consumption before myocardial infarction: results from the Kaiser-Pernamente epidemiologic study of myocardial infarction. Ann Intern Med 1974:81:294-301.

2 St Leger AS, Cochrane AL, Moore F. Factors associated with cardiac mortality in developed countries with particular reference to the consumption of wine. Lancet 1979;313:1017-20.

3 Knott CS, Coombs N, Stamatakis E, Biddulph JP. All cause mortality and the case for age specific alcohol consumption guidelines: pooled analyses of up to 10 population based cohorts. BMJ 2015;350:h384.
4 Brody JE. A few drinks may curb heart attacks. New York Times 20 Mar 1979. http://beta. industrydocuments.library.ucsf.edu/tobacco/docs/nydw0123.

5 Casswell S. Population level policies on alcohol: are they still appropriate given 'alcohol is good for the heart'? Addiction 1997;92(Suppl 1):S81-90.

6 Casswell, S. Public discourse on the benefits of moderation: implications for alcohol policy development. Addiction 1993;88:459-65.

7 International Center for Alcohol Policies. Drinking and cardiovascular health. ICAP policy tools series: health briefings, 2008. www.icap.org/Portals/0/download/all pdfs/Policy\% 20Tools/Drinking\%20and\%20Cardiovascular\%20Health.pdf.

8 Winemakers' Federation of Australia. Wine and health responsible winery initiative. 2014. www.wfa.org.au/responsible/wine-and-health/.

9 Stockley CS. Chair of WineHealth 2013 scientific advisory committee. [Editorial.] Nutr Aging 2014;2:77-9.

10 National Heart Foundation of Australia. Antioxidants in food, drinks and supplements for cardiovascular health. [Position statement.] 2010. www.heartfoundation.org.au/ SiteCollectionDocuments/Antioxidants-Position-Statement.pdf.

11 American Heart Association. Alcohol and heart health. 2014. www.heart.org/HEARTORG/ GettingHealthy/NutritionCenter/HealthyEating/Alcohol-and-Heart-Health_UCM_305173 Article.jsp.

12 Fekjær HO. Alcohol-a universal preventive agent? A critical analysis. Addiction 2013;108:2051-7.

13 Naimi TS, Brown DW, Brewer RD, Giles WH, Mensah G, et al. Cardiovascular risk factors and confounders among nondrinking and moderate-drinking U.S. adults. Am J Prev Med 2005;28:369-73.

14 Fillmore KM, Kerr WC, Stockwell T, Chikritzhs T, Bostrom A. Moderate alcohol use and reduced mortality risk: Systematic error in prospective studies. Addiction Res Theory 2006;14:101-32.

15 Chikritzhs T, Stockwell T, Naimi T, Andreasson S, Dangardt F, Liang W. Has the leaning tower of presumed health benefits from 'moderate' alcohol use finally collapsed? Addiction 2015, published online first 22 Jan. doi:10.1111/add.12828.

16 Holmes MV, Dale CE, Zuccolo L, Silverwood RJ, Guo Y, Ye Z, et al. Association between alcohol and cardiovascular disease: Mendelian randomisation analysis based on individual participant data. BMJ 2014;349:94164.

17 Chan M. WHO director-general's address. The eighth global conference on health promotion, Helsinki, Finland, 2013.

18 Mason R, Neate R. Civil service boss John Manzoni to keep his brewery directorship. Guardian 10 Oct 2014. www.theguardian.com/politics/2014/oct/10/civil-service-boss-johnmanzoni-sabmiller-director.

19 SABMiller. Board composition. 2014. www.sabmiller.com/about-us/corporate-governance/ board-composition.

20 SABMiller. TalkingAlcohol. Women's issues. Beauty and diet. 2014. www.talkingalcohol. com. au/index. asp? pageid $=125$.

21 UK Parliament. Register of all-party groups (as at 19 December 2014). 2014. www. publications.parliament.uk/pa/cm/cmallparty/register/contents.htm.

22 World Health Organization. Global status report on alcohol and health. WHO, 2014. www. who.int/substance_abuse/publications/global_alcohol_report/en/.

Cite this as: BMJ 2015;350:h407

๑ BMJ Publishing Group Ltd 2015 